\title{
Young People and Urban Public Space in Australia-Creating Pathways to Community, Belonging and Inclusion
}

\author{
Mike DEE (Corresponding author) \\ Queensland University of Technology \\ Australia \\ E-mail: m.dee@qut.edu.au
}

Received: April 8, 2015 Accepted: September 6, 2015 Published: September 29, 2015

doi:10.5296/ijssr.v3i2.7403

URL: http://dx.doi.org/10.5296/ijssr.v3i2.7403

\begin{abstract}
Cities and urban spaces around the world are changing rapidly from their origins in the industrialising world to a post-industrial, hard wired surveillance landscape. This kind of monitoring and surveillance connects with attempts by civic authorities to rebrand urban public spaces into governable and predictable arenas of consumption. In this context of control, a number of groups are excluded from public space, such as some children and young people. This article discusses the surveillance, governance and control of public space environments used by children and young people in particular, and the capacity for their ongoing displacement and marginality, as well as possible greater inclusion.
\end{abstract}

Keywords: CCTV, Citizenship, Public Space, Surveillance, Young People

\section{Introduction}

Urban public spaces worldwide face a number of challenges in the relentless drive by civic authorities and developers to create and sustain 'spectacular' consumption precincts. Many of these places are situated at the centre of long established urban settlements whose destruction, transformation or securitisation, through processes of gentrification, is required to promote new urban lifestyle developments (Davis, 1995; Atkinson \& Easthope, 2008; Hollis, 2013). In these harsh conditions, it can be said that "Young urbanites form a marginalised age class. Their movement is restricted, out of fear and distrust, within aims to protect, monitored by city surveillance methods within the security-obsessed fabric” (Scott, 2002:306). 
Increasingly, both children and young people are “among those undesirable 'others' being driven out of public space by private security forces" over time (Valentine, 1996:65). An important cluster of issues are evident here, as children and young people are "selectively

constructed as "problem" and "other" with their concerns marginalised, their lifestyles problematised and their voices subdued" and this flows into their use of public space as their claims to it as an aspect of social citizenship, are usually cast as inferior or rejected as they "stand outside the formal polity" as "non-persons" (Brown, 1998:116). Such marginalisation has implications for the ways some children and young people view their position in a community and over 40 per cent of respondents in my research reported feelings of not being wanted or liked in their local community (Dee, 2008, 2013).

\section{Methodology}

The research was carried out through a self-completion survey, designed by young people in social planning and focus group sessions. The methodology included a modified Grounded Theory approach to data collection, coding and sorting, to excavate key themes emerging from the data for further, exhaustive analysis (Glaser, 2003). The challenge for any researcher employing grounded theory as a research methodology is formidable, due to the "labour intensive nature of the procedures of the management and processing of data and the development of theory" necessitating great dedication and due to its complexity, it may well diminish the active participation of children and young people as researchers (Harris, 2013).

Grounded theory begins with the text, The Discovery of Grounded Theory (Glaser and Strauss, 1967). A grounded theory is "readily applicable to and indicated by the data" and further, is "meaningfully relevant to and able to explain the behaviour under study" (Glaser and Strauss, 1967:3). In the spirit of grounded theory, as proposed by Glaser and Strauss in their 1968 work with hospital patients, Time for dying, the drafting of the survey instrument came from the young people themselves, in order that theory emerges from the data and the situational context, rather than from an existing body of accepted knowledge. They found hospital patients to be at the receiving end of the decision-making and power structures inscribed within the institution of the hospital.

Arguably, the social world of young people is no less complex than that of nurse-patient -doctor- institution interactions, as there are a range of disparate, contradictory discourses structuring the category of 'youth' (Saggers et al., 2004: 20). Young people are often situated as anti-social and delinquent as well as the "guardians of the future" and also as vulnerable in a cruel, adult world, where innocence must be guarded (Loader, 1996; Malone and Hasluck 2002, 2008). Young people also frequently find themselves at the receiving end of decision-making processes (White and Wyn, 2013) and this provides a relevant context for employing grounded theory as an analytical methodology. The direct involvement of the young people in the design of the survey instrument provided an "active" and dynamic element to the fieldwork (Moss \& Petrie, 2002). 


\section{The Survey Instrument}

The 1122 respondents were female (594) and male (528) aged 13-18, from 6 state high schools and 1 independent school in Brisbane, Australia. The survey instrument contained 17 questions:

- 1. As a young person, do you feel that you are negatively stereotyped by people in the community?

- 2 . Do you think there are enough youth facilities in your area?

- 3. How involved do you feel in your local community life?

- 4. Are you happy with the way your school/university/TAFE involves you in the community?

- 5. Looking at things from your perspective, would you say that the wider community where you live is aware of or concerned about your safety?

- 6. What does the word 'Citizenship' mean to you?

- 7. Are there public places such as malls, streets, parks and other places in your local area that you avoid due to safety issues?

- 8. Is your school/university/TAFE a place you think of as safe?

- 9. Do security cameras make you feel safe in using public places

- 10 . Should there be more security cameras in your local area?

- 11 . What would make your use of public places more enjoyable?

- 12 . What would make your use of public places safer?

- 13. Do you think using public places raises issues for the following?-people with disabilities, people who are gay, lesbian or bisexual, people from Indigenous backgrounds, people who are homeless, any other people?

- 14. Do you consider yourself to be any/some/all of the above? If so, please say here:

- 15. Please say whether you are: Male or Female:

- 16. Please give your age:

- 17. Anything else you want to say?

The relevant survey questions for this article asked respondents about negative stereotyping, security cameras, facilities for young people, involvement and personal safety in their local community and schools, the meaning of the word citizenship and feelings of belonging.

Their responses provide us with the following key lenses with which to further analyse broad issues around urban public space and the place of children and young people within it.

\section{Lens 1: Public space is contested}


Public space is a contested reality and a range of users exist with different levels of access to public space, depending on their power and societal status (Wilson, Rose et al., 2010). A useful way of understanding public space is suggested by Tonkiss (2005:67), in the square indicating "collective belonging", the café "representing social exchange" and the street, a place marked by "informal encounter" as the "basic unit of public life", a routine if necessary conduit for "marginal encounters" based on equal rights to be in public space and acting as "a simple expression of citizenship” (Tonkiss, 2005:68, 2015).

Public space bears the imprint of the dominant order and this contested space acts as a key site of resistance by subordinate groups (Crane and Dee, 2001). Cunneen (2001:182, refers to a "spatial politics” wherein Australian Indigenous people are constructed as a criminal and "untidy" group to be removed where possible from public spaces and places of their choosing. There are important points for non-Indigenous people here also, if judged as not consuming goods and services in an appropriate manner or simply being, as Norris and Armstrong (1998:142), note in relation to poor young people (and other disadvantaged groups) "out of time and out of place”.

The position of young people is one largely of constrained rights, where they can find themselves as the inferior party in respect of disputes within local communities over rights to use and occupy public space, which adults presume to exercise as a right of citizenship (Loader, 1996). Social citizenship rights are largely about quality of life issues and human dignity, guaranteed by the welfare state to ensure that individuals have the material wherewithal to take full part in society (Marshall, 1950). Civil, political and social citizenship rights are all relevant to children and young people as users of public space and link to a form of "spatial citizenship" in terms of liveability, social, spatial and emotional well-being and overall sustainability (Rowntree Foundation, 2011:15). These are necessary elements of becoming 'satisfactory' citizens in the broadest sense, as indicated by Jacobs (1965):

The tolerance, the room for great difference among neighbours-differences that often go far deeper than differences in colour are possible and normal only when streets of great cities have built-in equipment allowing strangers to dwell in peace together on civilised but essentially dignified and reserved terms. Lowly, unpurposeful and random as they may appear, sidewalk contacts are the small change from which a city's wealth of public life may grow (p.48)

Key observations from my research for this lens of contestation were:

- Some communities are less concerned about young people, than others;

- Most schools are safe, but a number are not. Teachers contribute to student's feelings of safety at school. School should be about belonging and inclusiveness.

\section{Len 2: Exclusion}

The perception by young people that they are excluded from participation in community life and decision making is considered by Measor and Squires (2000), in their study of children and young people 'congregating' in public spaces in Brighton, England. They point to a central 
concern posited over a lack of consultation on community matters. The young people reported a strong sense of exclusion from community life, "All too often young people were talked about, typically they were talked about as a problem. Rather less often they were talked to, still less did they appear to be listened to” (Measor \& Squires, 2000:256).

The richness and complexity of young people's use of a range of public and semi-public spaces is often downplayed or dismissed by those for whom public space is an adult territory (Valentine, 2004; Iveson, 2006). This was a key outcome for Harris (2013), in a study which extended my quantitative work, in focus groups and interviews with 106 young people from culturally diverse backgrounds aged 14 to 25, in five Australian cities. She argues that notions of unified places marked by desire for consensus misplaces the variegated nature of young people's connections to local communities and further afield, to the global society:

Young people are problematised within this discourse for taking up public space in inappropriate ways; and indeed, a mark of strong communities is their capacity to 'deal with' young people in the urban environment by corralling them into suitable activities while selecting some with leadership potential for consultation, and by imposing law and order regimes to delimit their use of public space (for example, curfews or harsh penalties for graffiti) under the imperative of keeping streets safe (p.92).

Key observations from my research for this lens of exclusion were as follows:

- Most young people feel negatively stereotyped by their community;

- Most local areas do not have enough youth facilities;

- Public spaces such as streets, parks and transport nodes should be clean, well maintained and well lit, should have more in the way of facilities, such as shaded areas and places and free events for young people supervised by human agents.

Not merely "under catered for in public open spaces" (Woolley, 2006:55) it can be said that children and young people (to varying extents due to age, location and socio-economic factors) are driven from "the street into their bedrooms" (Summers, 1995:9) where they are no longer "free-range more battery-reared" (McNeish and Roberts, 1995:3). Not only is their marginalisation from public space exacerbated, but their marginalisation from citizenship, as mere "citizens-in-the-making" and their active role in making and re-making public space or the "micro-spaces of citizenship" also goes largely unregarded, but not unwatched, through camera and other electronic surveillance through child protection (Harris, 2013:37).

\section{Lens 3: Young people (always?) under suspicion and surveillance}

For many commentators the routine CCTV surveillance of urban areas was first signalled by the 1993 murder in the UK of Jamie Bulger (Norris and Armstrong, 1999; Walby, 2006). Media coverage of the murder brought it to television screens across the globe and the CCTV footage from the roof of the Liverpool shopping centre (enhanced by NASA) indicated the power of CCTV not to prevent crime, but to parade the suspects, themselves children, before the nation (Finer and Nellis, 1998; Dee, 2000). The aftermath of the murder sparked a massive 
investment in CCTV infrastructure in the UK totalling more than 21 billion pounds from 1985-1999 and beyond (Wrenall, 2010; Stedman, 2011).

The ongoing intensification of surveillance marks a transition from paper based methods to 'new' data based surveillance or "scrutiny through the use of technical means to extract or create personal or group data, whether from individuals or contexts” (Marx, 2002: 2) and includes DNA analysis, data profiling, matching and mining, CCTV with enhanced definition and predictive functionality and imaging and scanning capabilities (Marx, 2004). Regimes of new surveillance (unlike traditional surveillance) can be undertaken at a distance (such as aerial drones equipped with CCTV, sound recording and public address capabilities) with "sponge-like absorbency and laser-like specificity" requiring self-surveillance and the surveillance of others, in the workplace or community (Marx, 2002:3, Nelkin and Andrews, 2003).

However, questions of power, governance and democracy in relation to the development and deployment of surveillance measures remain. While on one level, surveillance is "the collection and processing of personal data, whether identifiable or not, for the purposes of influencing or managing those whose data have been garnered' (Lyon, 2001:2) at another level, surveillance "tries to make visible the identities or behaviours of people of interest to the agency in question” (Lyon, 2002:2). The work of Foucault (1974, 1977), provides critical insight here for the further interrogation of issues of power, information and surveillance.

Foucault was concerned with Bentham's invention of the Panoptican or Inspection House, based on an isolated, regularly structured place in which the individual is subjugated to the norms of work, education and discipline (Haggerty and Ericson, 2006). Situated within the Panoptican, it is possible to sanction or reward individuals for their behaviour, as all activities are monitored. It is this surveillance gaze, internalised and at least in part embraced, by the subject-object that is fundamental to the exercise of surveillant power (Foucault, 1977):

There is no need for arms, physical violence, material constraints. Just a gaze. An inspecting gaze, a gaze which each individual under its weight will end by interiorising to the point that he is his own overseer, each individual thus exercising this surveillance over, and against himself (p.155).

The concept of the Panoptican connects with the discourse of "threatening youth" where certain young people, never quite sure if they are under surveillance, surveil themselves and the actions of other children and young people (Malone and Hasluck, 2002:7). Familial surveillance is also a requirement for families with dependants subject to Anti-Social Behaviour Orders or 'ASBO's' in the UK (Squires and Stephen, 2005). In this way, ASBOs (for those aged 10 and over lasting at least two years) act to both internalise and normalise the surveillance gaze, turning it inward on a families' own children, often on pain of financial and criminal penalty if the object of the panoptic gaze should escape the modern home-cum-entertainment-cum detention centre (Valentine, 2004; Kearns and Collins, 2006).

While researchers argue that surveillance is not inherently designed to perpetuate inequality, they note that in contemporary society, where everyone is subject to some forms of 
surveillance "not everyone is monitored in the same way or for the same purposes" (Gilliom, 2001:48). Surveillance practices tend more often than not, to "coagulate more heavily on the more disadvantaged members of society" such as young people (Henman and Marston, 2008:201). Children and young people are highly visible users of urban public space as they have limited resources to effectively shield their presence from public view (White 1990; Dee 1995, Crane and Dee, 2001). According to Loader (1996) this visibility is a major factor:

More than any other social group, young people are dependent on a range of public places, especially in relation to the pursuit of leisure. Denied access (initially, at least, by reason of age) from a whole host of cultural amenities, young people come to rely on local streets, city centres, shopping malls and the like as a means to build cultural identities away from the direct supervision of adult authority. Their social practices - both legal and illegal - are thus rendered public and visible (p.69).

Their "visibleness" (Dwyer, 2010:2) is a key issue for civic authorities increasingly concerned not just with what they do or might do in public space, but with what they wear including the now infamous 'hoody'. As frequent "hanging out" (White, 1990:8) users of public space, children and young people are the target of a range of surveillance and control strategies including being 'moved on' and “over policed” (Blagg and Wilkie, 1995:2), "under policed" (Loader,1996:50) and in the UK, subject to "Anti-Social Behaviour Orders, Dispersal Orders and Curfew Orders” (Flint, 2006:53). As Norris and Armstrong (1999), noted presciently, the CCTV surveillance-control gaze is far from neutral:

The gaze of the cameras does not fall equally on all users of the street but on those who are stereotypically predefined as potentially deviant, or through appearance and demeanour, are singled out by operators as unrespectable. In this way youth, particularly those already socially and economically marginal, may be subject to even greater levels of authoritative intervention and official stigmatisation, and rather than contributing to social justice through the reduction of victimisation, CCTV will merely become a tool of injustice through the amplification of differential and discriminatory policing (p.279).

Key observations from my research for this surveillance lens were as follows:

- Public spaces such as streets, parks and transport nodes need supervision by human agents- camera surveillance alone does not give confidence that personal safety is assured;

- CCTV did not make respondents feel safe when using public places;

- Conversely perhaps, roughly equal numbers of respondents said there should be more CCTV as were opposed to further installation of CCTV;

- Key issues for many respondents centred on appropriate locations for CCTV, and its effectiveness in protecting them from harm in public space, rather than buildings.

In addition to CCTV, there are recent innovations in the repertoire of public space controls such as the mosquito, a device emitting a high pitched noise directly targeting children and 
young people under the age of 25 because their hearing is not yet fully developed (Institute for Public Policy Research, 2006). Clearly, such a blunt instrument with blanket coverage over a forty metre range fails to differentiate fairly between groups or individual children and young people and more importantly, brooks no discussion about rights to use and enjoy public space in the same way that other age groups do (Ivseon, 2006). There is now a substantial body of critical material pointing to a social sorting and ordering of public space (Zurawski and Czerwinski, 2008) by civic authorities around the world that is almost entirely driven by support for 'conspicuous consumption' and the exclusion, or at best, conditional inclusion, of 'flawed consumers’ or ‘vagabonds' (Baumann, 1998:14).

CCTV and other modes of surveillance are central to attempts to govern and contain the potentially "dangerous classes” (MacDonald, 1997:47) who are financially poor or simply maladapted to meet the required neo-liberal value set of "gentrified" and "creative cities" as places fit for conspicuous consumption (Atkinson and Easthope, 2009:71). Efforts to erect 'rings of steel' around Central Business Districts to give comfort to desired users of public with pledges of 'safe' family shopping/entertainment/lifestyle environments, are sustained at public expense to ensure private accumulation, but often run counter to civic advertising playing on the importance of 'celebrating diversity' and the inclusion of all in 'the community’ including children and young people (Clavell, 2011; Dee, 2015).

\section{Lens 4: Citizenship, Identity and Belonging}

The importance of a sense of belonging to positive and secure identity formation and good physical, psychological, emotional and even spiritual wellbeing has been gaining prominence over a number of years (Zapf, 2011). Viewing urban public space from a range of perspectives encourages different vantage points to emerge and questions around health, wellbeing and public space are increasingly topical and important in the broadest of public policy terms, with public space being a key arena for physical activity, mental health, commercial, cultural and community life and the possibility of social inclusion.

In my research, asking respondents what the word 'citizenship' meant to them yielded a large amount of qualitative data, ranging from one or two words, to sentences and a meta-narrative emerged from aggregating similar responses constructing a system of meaning, positioning citizenship within a cluster of related concepts; community-belonging-involvement-inclusion. The word citizenship carries important meanings for most young people (in my research) around belonging, community and taking part in community and national life. The following comments from the survey indicate the importance of citizenship, as an expansive rather than exclusionary sense of belonging within an overarching notion of community:

- Citizenship is being a citizen of an area or community, which is involved in its activities etc. (Female 15)

- Citizenship means belonging to and participating in a community-be it local, national or global (Male 17)

- Citizenship is being a part of the community. Trying to help make your community a better place (Male 14) 
- That word to me, (citizenship) means people in the community who are civilised, responsible, trusting (Female 15)

For many young people feeling wanted and being a part of their local and wider community is central to their identity formation and coherence both as a human and as a citizen. In this way as Chawla (2002), suggests, the link between public space being the public realm and a sense of oneself as a citizen, is constructed from the earliest good and bad, experiences:

The criteria by which young people evaluate their local environments form important indicators for several reasons. Children's happiness is a good in itself, to be prized in the moment. A further benefit is that through satisfying experiences in the public realm, children have opportunities to grow into new roles and competencies. In the long term, the experiences of childhood form a foundation for the 'habits of the heart' of adulthood, in the sense of people's accustomed relationships to their community, public life and public space (p. 221).

These patterned and accustomed relationships, as Chawla (2002), notes are crucial to children and young people growing up well in terms of sustained linkages and attachment to people, places and the fabric of public space (Woodman and Wyn, 2015). As one of the respondents in my survey commented, citizenship means being:

- Someone who belongs somewhere and provides a place with ideas, safety, health and happiness, to make a better environment for everyone (Female 15)

For the young people in my study, the word citizenship had a broad span of meanings, centred on belonging within a local community, indicated by a sense of inclusion and opportunities for involvement in the life of that community. Young people have an important contribution to make in community building and along the way can consolidate their personal sense of belonging as citizens. This is an important departure from the often negative feelings towards and about young people reported in the survey comments and also in the work of Chawla (2002). Rarely, however are children and young people actively and respectfully brought into planning and governance processes and consequently many urban public spaces are essentially adult places, where control and ongoing surveillance are the key concerns and inclusion of children and young people a commercially driven afterthought (Harris, 2013).

\section{Conclusion}

This article considered questions of social citizenship rights and discourses of health and wellbeing and suggests that cities, places and spaces and those who seek to use them, can be resilient in maintaining and extending democratic freedoms, calling surveillance, planning and governance systems to account (Minton, 2012). However, the highly publicised and promoted policy aim of inclusion can and does lead to forms of exclusion and attempting to make urban places 'safe' for approved activities and social actors may become self-defeating in the forcible exclusion of so many "dangerous others" (Watson, 2006:65), that the public space remaining is bereft of any excitement, or real diversity and difference. 
So called 'safe' public space is predictable and patterned, largely as civic authorities and corporate entities require it to be, but lacking in the nurturing of engagement and social citizenship of encountering and understanding difference and practicing tolerance, essential elements of a confident and sophisticated urban population (Jacobs, 1965; Sennett, 1976). Conversely, it can be said that places that work well for children and young people, that have a good level of amenity and provision, that are genuinely inclusive, go a long way to meeting the needs of all users of public space (Morrow, 2002; Freeman, 2006; Dee, 2008).

It is exactly at these times of civic and commercial control, facilitated by general security concerns that so called "defensive architecture" to ward off the homeless, imagined ne'er do wells and numerous others, installed outside major shops, banks and other private buildings exemplifies the impact of exclusionary power (Andreou, 2015:1):

From ubiquitous protrusions on window ledges to bus-shelter seats that pivot forward, from water sprinklers and loud muzak to hard tubular rests, from metal park benches with solid dividers to forests of pointed cement bollards under bridges, urban spaces are aggressively rejecting soft, human bodies.

In this way, the humanity and citizenship of the urban setting is constantly revised, curtailed and potentially deleted, at least for some groups and individuals. Resistance to the over wrought surveillance and security gaze and burgeoning Big Data infrastructure is now all the more important, in these complex times of austerity and declining welfare states. This makes a consideration of the importance and value of notions of civil, social and political citizenship, as originally discussed by Marshall (1950), as fostering full participation and genuine inclusion in the national social life, both urgent and apposite.

\section{Acknowledgement}

The author wishes to thank the IJSSR reviewers for their useful and constructive comments.

\section{References}

Andreou, A. (2015). Anti-homeless spikes: 'Sleeping rough opened my eyes to the city's barbed cruelty”. The Guardian. Retrieved February 19, 2015, from http://www.theguardian.com/society/2015/feb/18/defensive-architecture-keeps-poverty-undee n-and-makes-us-more

Atkinson, R., \& Easthope, H. (2009). The consequences of the Creative Class: The Pursuit of Creativity Strategies in Australia's Cities. International Journal of Urban and Regional Research, 33, 64-79. http://dx.doi.org/10.1111/1468-2427.12205

Bauman, Z. (1998). Work, consumerism and the new poor. Buckingham: Open University Press.

Blagg, H., Wilkie, M., \& Australian Youth Foundation. (1995). Young people and police powers. Sydney: The Australian Youth Foundation.

Brown, S. (1998). Understanding youth and crime-Listening to youth? Open University Press: Buckingham. 
Chawla, L. (Ed.). (2002). Growing Up in an Urbanising World. London: UNESCO/Earthscan Publications.

Clavell, G. (2011). The Political Economy of Surveillance in the (Wannabe) Global City. Surveillance and Society, 8(4), 523-526.

Crane, P. \& Dee, M. (2001). Young people, public space \& New Urbanism. Youth Studies Australia, 20(1), 11-18.

Cunneen, C. (2001). Conflict, Politics and Crime-Aboriginal Communities and the Police. NSW: Allen \& Unwin.

Davis, M. (1995). Fortress Los Angeles: The Militarization of Urban Space. In P. Kasinitz (Ed.), Metropolis Centre and Symbol of our Times. London: Macmillan.

Dee, M. (1995). Caught on camera. Young People Now, pp. 18-19. Retrieved from http://eprints.qut.edu.au/view/person/Dee,_Michael.html

Dee, M. (2000). The use of CCTV to police public Spaces: A case of Big Brother or Big Friend? Paper Presented at the 27th International Conference on Making Cities Liveable, Vienna Town Hall, Austria, July 2000. Retrieved from http://eprints.qut.edu.au/view/person/Dee,_Michael.html

Dee, M. (2008). Young People, Public Space and Citizenship. Unpublished PhD thesis, Queensland University of Technology. Retrieved from http://eprints.qut.edu.au/view/person/Dee,_Michael.html

Dee, M. J. (2013). Welfare surveillance, income management and new paternalism in Australia. Surveillance and Society, 272-286. Retrieved from http://library.queensu.ca/ojs/index.php/surveillance-and-society/

Dee, M. J. (2013). Citizenship, community, public space and the marginalisation of children and young people, Proceedings of The Australian Sociological Association (TASA) Conference 2013 p1-14. https://www.tasa.org.au/

Dee, M.J, (2015). Urban citizenship in a sensor rich society. International Journal of Social, Education, Economics and Management Engineering, 76-81.

Finer, C. \& Nellis, M. (Eds.). (1998). Crime and Social Exclusion. Oxford Blackwell.

Flint, J. (2006). Surveillance and exclusion practices in the governance of access to shopping centres on periphery estates in the UK. Surveillance and Society, 4(1/2), 52-68.

Foucault, M. (1974). The Order of Things: An Archeology of the Human Sciences. London: Routledge.

Foucault, M. (1977). Discipline and Punish: The Birth of the Prison. London: Allan Lane.

Freeman, C. (2006). Colliding worlds: planning with children and young people for better cities. In Gleeson, B \& Snipe, N. (Eds.), Creating Child Friendly Cities. London: Routledge. 
Gilliom, J. (2001). Overseers of the Poor: Surveillance, Resistance, and the Limits of Privacy. Chicago: University of Chicago Press.

Glaser, B., \& Strauss, A. (1967). The Discovery of Grounded Theory-Strategies for Qualitative Research. Chicago: Aldine.

Glaser, B., \& Strauss, A. (1968.). Time for dying. Chicago: Aldine.

Glaser, B. (2003). The Grounded Theory Perspective 2: Description's Remodeling of Grounded Theory Methodology. Mill Valley CA: Sociology Press.

Haggerty, K. and Ericson, R. 2006. The New Politics of Surveillance and Visibility. Toronto: University of Toronto Press.

Harris, A. (2013). Young People and Everyday Multiculturalism. London: Routledge.

Henman, P. (2004). Population Segmentation, Electronic Surveillance and Governing the Unemployed in Australia. International Sociology, 19(2), 173-191. www.isa-sociology.org/publ/is.html

Henman, P., \& Marston, G. (2008). The social division of welfare surveillance, Journal of Social Policy, 37(2): 187-206. http://dx.doi.org/10.1017/S004727941500029X

Hollis, L. (2013). Cities are Good For You. London: Bloomsbury. Institute for Public Policy Research. (2006). Cafe Politique: Big Brother policing: CCTV and Surveillance. Retrieved December 8, 2006, from www.ippr.org.uk

Iveson, K. (2006). Cities for angry young people? In Gleeson, B. \& Snipe, N. (Eds.), Creating Child Friendly Cities. London: Routledge.

Jacobs, J. (1965). The Life and Death of Great American Cities. New York: Random House.

Kearns, R. \& Collins, D. (2006). Children in the intensifying city: lessons from Auckland's walking school buses. In Gleeson, B. \& Snipe, N. (Eds.), Creating Child Friendly Cities. London: Routledge.

Loader, I. (1996). Youth, Policing and Democracy. London: Macmillan.

Lyon, D. (2002). Surveillance Studies: Understanding visibility, mobility and the phenetic fix. $\begin{array}{llll}\text { Surveillance } \quad \text { and } & \text { Society, } & 1(1),\end{array}$ http://library.queensu.ca/ojs/index.php/surveillance-and-society/

Lyon, D. (2001). Surveillance Society. Buckingham: Open University Press.

MacDonald, R. (Ed.). (1997). Youth, the 'Underclass' and Social Exclusion. London: Routledge.

Malone, K., \& Hasluck, L. (2002). Australian Youth. In L. Chawla (Ed.), Growing Up in an Urbanising World. London: UNESCO/Earthscan Publications.

Malone, K., \& Hasluck, L. (2008). Geographies of Exclusion. Family Matters No. 49 Autumn 1998. Australian Institute of Family Studies. 
Marshall, T. H., \& Bottomore, T. (1950). Citizenship and Social Class. London: Pluto.

Marx, G. T. (2002). What's New About the "New Surveillance”? Classifying for Change and Continuity, Surveillance and Society, 1(1), 9-29.

McNeish, D., \& Roberts, H. (1995). Playing it Safe: Today’s Children at Play. Ilford: Barnardos.

Measor, L., \& Squires, P. (2000). Young people and community safety: inclusion, risk, tolerance and disorder. Aldershot: Ashgate.

Minton, A. (2012). Ground Control. London: Penguin.

Morrow, V. (2002). Children's rights to public space: environment and curfews. In B. Franklin (Ed.), The New Handbook of Children's Rights. London: Routledge.

Moss, P. and Petrie, P. (2002). From Children's Services to Children's Spaces-Public Policy, Children and Childhood. London: Routledge/Falmer.

Nelkin, D. \& Andrews, L. (2003). Surveillance creep in the genetic age. In Lyon, D. (ed.) Surveillance as Social Sorting. London: Routledge.

Norris, C., \& Armstrong, G. (1999). The Maximum Surveillance Society: The rise of CCTV. Oxford: Berg. Rowntree Foundation, the Joseph (2011). The social value of public spaces. Joseph Rowntree Foundation, York.

Saggers, S., Palmer, D., Royce, P., Wilson, L., \& Charlton, A. (2004). Alive and Motivated: Young People, Participation and Local Government. Canberra: National Youth Affairs Research Scheme.

Scott, C. (2002). Citizenship education: who pays the piper? In B. Franklin (Ed.), The New Handbook of Children's Rights. London: Routledge.

Sennett, R. (1976). The Fall of Public Man. New York: Knopf.

Short, J. (1989). The Humane City. Oxford: Basil Blackwell.

Sibley, D. (1995). Geographies of Exclusion: Society and Difference in the West. London: Routledge.

Squires, P., \& Stephen, D. (2005). Rethinking ASBOs. Critical Social Policy, 25(4), 517-528. http://dx.doi.org/doi:10.1177/0261018315578107

Stedman, A. (2011). The camera never lies, or does it? The dangers of taking CCTV surveillance at face value. Surveillance and Society, 8(4), 527-534.

Summers, D. (1995). A modern child's home appears to be its refuge. Financial Times, 25th April.

Tonkiss, F. (2005). Space, the City and Social Theory. Cambridge and New York: Polity Press. 
Valentine, G. (2004). Public Space and the Culture of Childhood. Aldershot: Ashgate.

Walby, K. (2006). Little England? The rise of open-street Closed Circuit Television surveillance in Canada. Surveillance and Society, 4(1/2): 29-51.

Watson, S. (2006). City Publics-The (dis)enchancements of urban encounters. Oxon and New York: Routledge.

White, R., \& Wyn, J. (2013). Youth and Society, exploring the social dynamics of youth experience (3rd ed.). Melbourne: Oxford University Press.

White, R. (1990). No Space of Their Own-Young People and Social Control in Australia. Melbourne: Cambridge University Press.

Wilson, D., Rose, J. \& Colvin, E. (2010) Marginalised Young People, Surveillance \& Public Space. Youth Affairs Council of Victoria.

Woodman, D. \& Wyn, J. (2015). Youth and Generation. London: Sage

Woolley, H. (2006). Freedom of the city: contemporary issues and policy influences on children and young people's use of public open space in England. Children's Geographies, 4(1), 45-59. http://dx.doi.org/10.1080/14733285.2006.89328010.

Wrennal, L. (2010) Surveillance and Child Protection: De-mystifying the Trojan Horse, Surveillance and Society, 7(3/4), 304-324.

Zapf, M. K. (2010). Social Work and the Environment: Understanding People and Place. Critical Social Work, 2010 Vol. 11, No. 3. Retrieved from www1.uwindsor.ca/criticalsocialwork/social-work-and-the-environment

Zurawski, N., \& Czerwinski, S. (2008). Crime, Maps and Meaning: Views from a Survey on Safety and CCTV in Germany. Surveillance and Society, 5(1), 51-72.

\section{Copyright Disclaimer}

Copyright for this article is retained by the author(s), with first publication rights granted to the journal.

This is an open-access article distributed under the terms and conditions of the Creative Commons Attribution license (http://creativecommons.org/licenses/by/3.0/). 